S. Richter, M. Braun-Unkhoff, C. Naumann, U. Riedel, Paths to alternative fuels for aviation, CEAS Aeronautical Journal 9 (2018) 389-403.

The original publication is available at www.springerlink.com

https://doi.org/10.1007/s13272-018-0296-1 


\title{
Paths to alternative fuels for aviation
}

\author{
Sandra Richter*, Marina Braun-Unkhoff, Clemens Naumann, Uwe Riedel \\ Institute of Combustion Technology, German Aerospace Center (DLR) \\ Pfaffenwaldring 38-40, 70569 Stuttgart, Germany
}

*corresponding author: Sandra.Richter@dlr.de, phone: +49 71168628202

\begin{abstract}
Almost the complete amount of jet fuel available on the global market is produced from fossil crude oil being an exhaustible raw material. Furthermore, its use is inherently connected with emissions of the greenhouse gas $\mathrm{CO}_{2}$. To cope with this, several processes for the production of alternative aviation fuels were developed including the use of biomass as a renewable feedstock. Since biomass from cultivation farming is in competition with food and fodder production, the preferred raw material would be residues from agriculture and forestry or municipal waste, also microalgae can be used. Independent of the raw material, the conversion of biogenic feedstock into alternative jet fuel is based on microbial, thermal and/or chemical breakdown of larger (bio)-molecules into smaller ones, followed by the catalytic formation of fuel molecules and hydrogenation. An overview on the production of different alternative bio-based jet fuels is given including a survey about producers and capacities, focusing on already certificated bio-based jet fuels.

In addition to that, a comparison of fundamental combustion properties between Jet A-1 and different alternative jet fuels is presented: Laminar burning velocities and ignition delay times, each measured for two synthetic jet fuels based on fossil resources (coal-to-liquid - CtL and gas-to-liquid - GtL) as well as for two biofuels (farnesane and an Alcohol-to-Jet fuel - AtJ). Measurements of the burning velocities were performed at a preheat temperature of $473 \mathrm{~K}$ and pressures of 1 bar and 3 bar by variation of the fuel-air-equivalence ratios $\varphi$. Ignition delay times were determined for $\varphi$-values of $0.5,1.0$, and 2.0, at an initial pressure of about 16 bar and temperatures ranging between $800 \mathrm{~K}$ and $1700 \mathrm{~K}$. It turns out that with respect to the characteristic combustion properties tested the considered alternative fuels have a combustion behavior similar to Jet A-1.
\end{abstract}

\section{Keywords}

Alternative jet fuels; biofuel production; Fischer-Tropsch process; HEFA; farnesane; Alcohol-to-Jet; ignition; laminar flame speed.

\section{Introduction}

Our modern world is characterized by a high mobility, people using automobiles, trains, ships or aeroplanes. Today and most probably also in the upcoming decade, this mobility is almost completely driven on the combustion of liquid fuels, still made from crude oil to a large extent. Small amounts are already synthetic (alternative) fuels, since other energy carriers $e . g$. batteries do not have such a high energy density yet. But the use of these fuel types has two important drawbacks: (i) The crude oil sources are limited; (ii) The exhaust gases contribute to the increase of the greenhouse gas carbon dioxide $\left(\mathrm{CO}_{2}\right)$, pollutants like nitrogen oxides $\left(\mathrm{NO}_{\mathrm{x}}\right)$, sulphur compounds, and also to particulate matter and heavy metals (in traces). Especially in the aviation sector these emissions should be noted because they are released mostly at an altitude between about 10 and $13 \mathrm{~km}$ into the upper troposphere (lower atmospheric layer where the weather pattern takes place) and tropopause (boundary layer between troposphere and stratosphere) respectively. Here contrails and particle induced cirrus clouds are formed due to the exhaust gases of an aircraft which affects the radiation balance of the earth's atmosphere $[1,2]$. In addition, emissions are occurring during take-off and landing, at ground or near-ground [3].

The use of biomass as a feedstock for fuel production is one way to address these points. The European Union (EU), several airlines, and partners from industry are promoting the utilization of biofuels e.g. by having launched the 'Biofuels Flightpath Initiative', with the goal to use two million tons of biofuels per year for aviation in Europe beyond 2020. For comparison, in 2010 the total consumption of aviation fuels was 53 million tons in Europe [4]. Starting with test flights in 2008 using the first bio-jet fuel blends [5], the current development shows that more and more airlines use sustainable aviation fuels for (selected) regularly flights and close long-term delivery contracts [6-10]. Among these airlines are for example United Airlines [11], Lufthansa [12], KLM [13], Alaska Airlines [14], and Cathay Pacific [15].To rate also the sustainability of these synthetic fuels, it must be studied from which type of resource the specific biofuel was produced.

Depending on the raw material, three generations of biofuels are discerned. The first generation comprises biofuels made from vegetable oils, sugar or starch by 
conventional techniques of production. The easiest ways to convert these kinds of biomass into biofuels are e.g. the fermentation of sugar (or starch) to bioethanol and the transesterification of vegetable oils into biodiesel. But since both contain oxygen atoms they cannot be used directly as jet fuel without further conversion, due to the ASTM certification. Moreover, vegetable oils can be converted to HEFA (Hydrotreated Esters and Fatty Acids) fuel. However, these kinds of biofuels are in competition to traditional agriculture for food and forage production not only because crop and oil plants are cultivated for the food industry, but also due to the competition between the different usages of the cultivable land. Of course, there is the possibility to create new crop areas by reallocation of land use; but then, a possible $\mathrm{CO}_{2}$-sink (by plants) would be diminished [16], besides further negative effects on the environment, such as reducing bio-diversity.

To cope with these problems, increased efforts are devoted to produce the so-called second generation of biofuels: The raw materials for these advanced biofuels are residues from agriculture and forestry or other lignocellulosic (woody) biomass. Unfortunately, the production of second generation biofuels is not as easy as for the first generation biofuels. More complex processes are necessary, like a pre-treatment with enzymes or microorganisms or a thermochemical conversion. An example for a second generation biofuel is Fischer-Tropsch kerosene made from wooden material as described below in section 2.1. Also, used cooking oils, animal fat from cadavers etc. can be added to the feedstock for second generation biofuels.

The advantages of both first and second generation biofuels are combined in the third generation $-e . g$. micro and macro algae. They yield a high amount of lipids, which have a similar structure as vegetable oils, with no competition to any kind of agriculture. Additionally, they can grow in waste water and may use $\mathrm{CO}_{2}$ from industrial exhaust gases [16]. To promote the research and development in this technology the 'European Network for Algal-Bioproducts' (EUAlgae) was established [17]. Furthermore, companies like e.g. Total already invest in development projects to cultivate micro algae for fuel production [18].

In principle, the facts about biofuels as well as problems concerning emissions and crude oil apply to all major liquid transportation fuels - kerosene, gasoline, and diesel. But due to safety reasons, a jet fuel has to match stricter requirements [2] as it has to pass a certification process, as defined by the American Society for Testing and Materials (ASTM). That counts for conventional crude-oil based as well as for alternative aviation fuels [19]. For example, the certification includes specifications for concentrations of different compounds like aromatics or inorganic trace substances, but also physical properties [5] e.g. specific energy density, and combustion properties. Furthermore, there are special safety requirements concerning storage, transportation, and pumping properties; in addition, global availability is essential [20,21].

Up to now five different alternative jet fuels have been certified by ASTM defining them as drop-in-fuels; thus, they can be used without any modification in existing airplanes and infrastructures (e.g. on seals, fittings, fuel supply system, etc.) when blending with conventional jet fuels according to ASTM D7566 [3, 22].

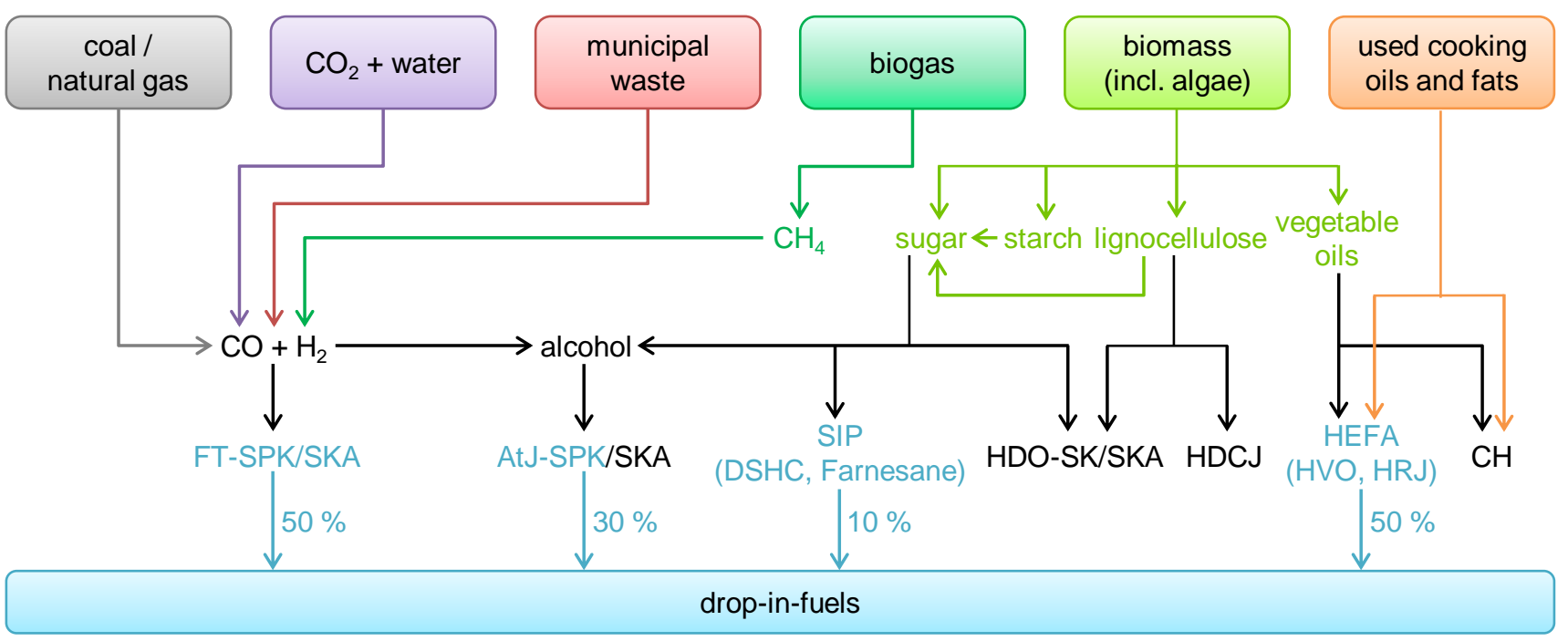

Fig. 1 Survey of different kinds of raw materials for alternative fuel production, important intermediate products and different alternative jet fuels (AtJ - Alcohol-to-Jet, CH - Catalytic Hydrothermolysis, DSHC - Direct Sugar to Hydrocarbons, FT - Fischer-

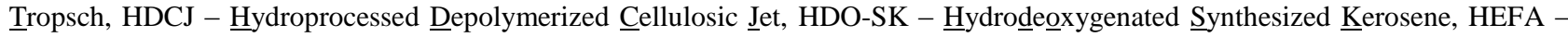
$\underline{H}$ ydrotreated Esters and Fatty Acids, HRJ - Hydroprocessed Renewable Jet, HVO - $\underline{\text { Hydrotreated }} \underline{\text { Vegetable }} \underline{\text { Oils, }}$ SIP - $\underline{\text { Synthesized }}$ Iso-Paraffins, SKA - Synthesized Kerosene with Aromatics, SPK - Synthesized Paraffinic Kerosene) 
The possible percentage of the drop-in-fuel component in such a jet fuel blend ranges from $10 \%$ up to $50 \%$ depending of the kind of the alternative fuel (see also Fig. 1). In addition, there are even more synthetic fuels being suitable as bio-blending components. Alternative fuels being at the moment under discussion and their sources are presented in Fig. 1; fuels written in blue are the five certified ones: two different kinds of FischerTropsch (FT)-fuels, HEFA kerosene, farnesane, and an Alcohol-to-Jet (AtJ) fuel [23].

In the present paper, for the five alternative fuels mentioned, an overview of the production process, including a survey of manufacturers and capacities, will be given; also by referring to two fundamental combustion properties - laminar burning velocity and ignition delay time. Future possibilities to produce aviation fuels from biomass will be reviewed as well.

\section{Alternative fuels for aviation}

Besides biomass, other raw materials being suitable for the production of different kinds of sustainable jet fuels exist. An overview of feedstocks and alternative aviation fuels as well as important intermediate products is given in Fig. 1.

In the following section, all alternative jet fuels already certificated [23] will be considered closer addressing their production pathway(s) and manufacturer(s). In addition, current efforts to promising synthetic jet fuel candidates, in particular (i) $\mathrm{CH}$ (catalytic hydrothermolysis) kerosene, (ii) HDO (hydro-deoxygenated) kerosene, and (iii) HDCJ (hydro-processed depolymerized cellulosic jet) kerosene will be discussed, too.

\subsection{Fischer-Tropsch fuels}

The first works on the Fischer-Tropsch (FT) synthesis in 1925 were the basis for the development of a new process for the production of liquid fuels made from coal [24]. And so, today the FT-process is a well-known technique for the production of synthetic hydrocarbons (fuels). In South Africa, the chemical and energy company Sasol operates an industrial-scale plant for the production of the so called coal-to-liquid (CtL)-fuel [25]. Besides coal as raw material, natural gas can be exploited; plants using natural gas are established by Shell producing a gas-to-liquid (GtL)-fuel at two large facilities [26]. Even methane obtained from biogas (major component) can be processed to a renewable (biogenic) GtL-fuel; but, till now, neither a plant exists nor is planned in the near future [20]. However, using fossil resources - coal and natural gas - is no appreciable improvement with respect to sustainability and the needed reduction in $\mathrm{CO}_{2}$ emissions. Both issues can be accomplished only with the use of biomass as feedstock

The most preferable way is the usage of lignocellulosic material like wooden residues from forestry or woodprocessing industry, wood from short rotation forestry and also agricultural residues (like straw) [20, 27, 28]; in principle, all kinds of biomass could be used. Moreover, with the use of municipal waste as feedstock [19, 29], there is additional potential to protect the environment by recycling, resulting in a waste-to-liquid (WtL)-fuel.

The major process steps for producing a FT-fuel are summarized in Fig. 2. As an example, the following description of the principles of the FT-process uses wood, the most common sustainable resource $[19,28]$.

1) Pre-treatment. The woody biomass has to be subjected to different pre-treatment steps starting with shredding and drying followed by torrefaction. Thus, large lignocellulosic molecules are decomposed into smaller ones, at temperatures in the range between $200{ }^{\circ} \mathrm{C}$ to $300{ }^{\circ} \mathrm{C}$ and atmospheric pressure, without oxygen present [27]. After this thermal conditioning, a mechanical grinding takes place. Torrefaction usually leads to more energy-dense fuel carrier.

2) Syngas production. The crushed organic material is converted to syngas in a gasification process at temperatures ranging from $800{ }^{\circ} \mathrm{C}$ to $1800{ }^{\circ} \mathrm{C}$ using oxygen and steam as gasification agents [29]. The resulting syngas consists of carbon monoxide $(\mathrm{CO})$ and hydrogen $\left(\mathrm{H}_{2}\right)$ in different amounts, the ratio depends on the raw material. Whereas the production of syngas is mostly independent of the feedstock and essential for every FT-process.

3) Syngas refinement. Before using syngas for the subsequent FT-synthesis, firstly syngas has to be purified, by removal of dust, slack, nitrogen, and sulphur compounds. Secondly, the $\mathrm{CO}-\mathrm{H}_{2}$-ratio must be adjusted with respect to the product of interest, mostly via the watergas-shift reaction $\mathrm{CO}+\mathrm{H}_{2} \mathrm{O} \rightleftharpoons \mathrm{CO}_{2}+\mathrm{H}_{2}$; thus, $\mathrm{CO}_{2}$ and water are removed from the syngas.

4) FT-synthesis. Now the underlying FT-synthesis, the reaction with $\mathrm{CO}$ and $\mathrm{H}_{2}$ forming hydrocarbons, is processed, with the help of steam and a catalyst, mostly iron or cobalt based. Depending on the process temperature, there are two different options for the overall process management: a high and a low temperature synthesis at about $340{ }^{\circ} \mathrm{C}$ and $230{ }^{\circ} \mathrm{C}$, respectively [27]. With the selection of the catalyst and the process conditions, the kind of product and the product yield are influenced [30], e.g. with respect to carbon length and ratio of high/low boiling products resulting in higher amounts of kerosene or diesel, respectively, besides further products.

5) Isomerization and branching. The crude FT-fuel consists mainly of linear hydrocarbon chains. These n-alkanes, also called n-paraffins, have to be isomerized partially in a refining process stage to generate branched fuel molecules, iso-alkanes, in order to match the freezing point of a jet fuel according to the specification [21]. To raise the yield for jet fuel, it is further possible to perform either an oligomerization of lighter hydrocarbons or a selective cracking reaction of heavier hydrocarbons [31]. However, the product will always be a mix of several products, not kerosene alone.

6) Distillation. Lastly, the pre-processed FT-fuel mix is separated in different single fuel fractions - fuel 
gas, naphtha, kerosene, and diesel - by distillation depending on the number of carbon atoms (chain length).

The resulting jet fuel is called 'Fischer-Tropsch synthetic paraffinic kerosene' (FT-SPK). The description 'paraffinic' implies that this synthetic jet fuel contains no aromatics, but primarily saturated compounds (alkanes). This is one reason why a FT-SPK jet fuel is only approved for a blend up to $50 \%$ (maximum) with conventional Jet A-1 as the specification affords a minimum aromatics content (> 8 vol.-\%) [19].

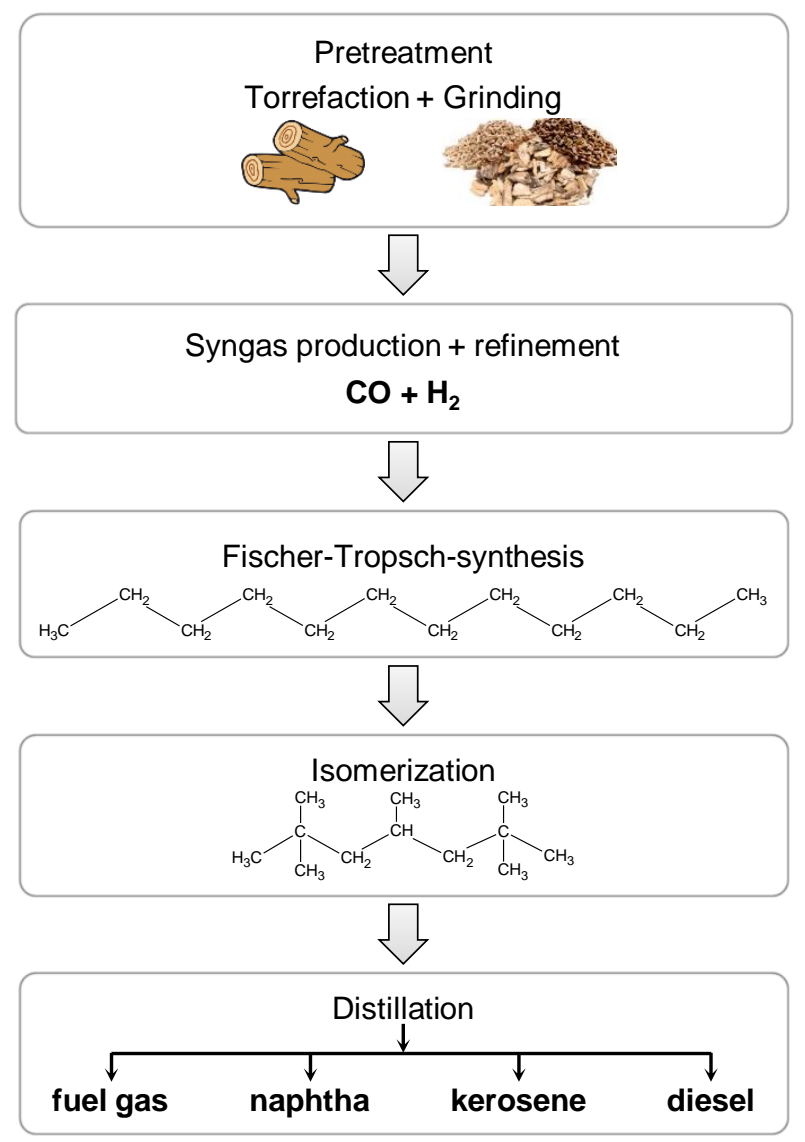

Fig. 2 Major process steps for the production of Fischer-Tropsch fuels made from wooden raw materials

Furthermore, during the refining process of the paraffinic syncrude, it is possible to add some aromatics: Either by aromatization of some fractions obtained within the low-temperature syncrude [31] or by mixing a naphtha fraction containing a small percentage of benzene [32], generated in the high-temperature synthesis [32] with alkylated mono-aromatics. The Fischer-Tropsch synthetic kerosene with aromatics (FT-SKA) has also the approval as a blending component (maximum 50 vol.-\%) to Jet A-1 [33].

Up to now, nearly all industrial-scale FT-plants are operated with coal or natural gas as feedstock. Recently, several initiatives were started aiming at the production of sustainable FT-fuels, see Table 1. For example, Red Rock Biofuels LLC offers a product capacity of 16 million gallons per year (approx. 48000 t/a) biofuels made from woody biomass [33]; for comparison: Sasol Synfuels (Pty.) Ltd. could achieve a capacity of 7.6 million tons synthetic jet fuels made from coal in 2014 [35]. Red Rock Biofuels LLC has an agreement with the transport company FedEx Corporation to provide them with three million gallons (approx. $9000 \mathrm{t}$ ) of biofuel per year [36]. Furthermore, Total SA announces to build a new plant to convert lignocellulosic material into biodiesel and bio-jet fuel until 2020 [37]. For WtL-fuels, there are promising developments, too: Fulcrum Bioenergy Inc. plans the start-up of a FT bio-refinery in 2020 where municipal solid waste will be converted into fuel. The facility for the conversion of the solid waste in a synthetic crude oil is already operating [38].

In addition to the mentioned sustainable raw materials (summarized in Table 1), research is ongoing to produce jet fuel by using carbon dioxide and water as the only feedstock. Although this strategy seems to be futuristic, it has been already demonstrated twice: Within the EUproject SOLAR-JET [39] and by the company Sunfire $\mathrm{GmbH}$ [40]. Both have shown that it is possible to generate syngas, step 2 within the FT-synthesis, from $\mathrm{CO}_{2}$ and water (steam). In the SOLAR-JET project, high temperatures are needed; a metal oxide was used as a catalyst in a solar reactor. With the help of focused sunlight, temperatures up to $2000{ }^{\circ} \mathrm{C}$ have been achieved. At such high temperatures, different oxidation states are formed by the reduction of the metal oxide. Subsequently, when steam and $\mathrm{CO}_{2}$ pass through the solar reactor, oxygen is abstracted from the gases resulting in the generation of $\mathrm{H}_{2}$ and CO (syngas) [41, 42]. Sunfire has developed a "Reversible Solid Oxide Cell" for the high-temperature electrolysis of steam into hydrogen and oxygen at about $800^{\circ} \mathrm{C}$. The energy required for the electrolysis should be gained from "green" electricity. Exploiting the water-gas shift reaction, carbon dioxide is converted to carbon monoxide, by using renewably produced hydrogen, also leading to the production of syngas [40, 43].

Table 1 Overview on current progress of sustainable FischerTropsch fuels, having no conflict to feed/food production

\begin{tabular}{|c|c|c|c|}
\hline Company & Feedstock & Capacity (t/a) & Comment \\
\hline $\begin{array}{l}\text { Red Rock } \\
\text { Biofuels [33] }\end{array}$ & $\begin{array}{l}\text { Woody } \\
\text { material }\end{array}$ & $\begin{array}{l}\text { 48,000 } \\
\text { approx. }\end{array}$ & $\begin{array}{l}\text { Cooperation } \\
\text { with FedEx } \\
{[36]}\end{array}$ \\
\hline Total [37] & $\begin{array}{l}\text { Ligno- } \\
\text { cellulose }\end{array}$ & & $\begin{array}{l}\text { Starting 2020, } \\
\text { diesel + jet }\end{array}$ \\
\hline $\begin{array}{l}\text { Fulcrum } \\
\text { Bioenergy } \\
{[38]}\end{array}$ & $\begin{array}{l}\text { Munici- } \\
\text { pal waste }\end{array}$ & $\begin{array}{l}30,000 \\
\text { approx. }\end{array}$ & $\begin{array}{l}\text { Starting fuel } \\
\text { production } \\
2020\end{array}$ \\
\hline Sunfire [41] & $\begin{array}{l}\mathrm{CO}_{2}+ \\
\text { water }\end{array}$ & & $\begin{array}{l}\text { Under devel- } \\
\text { opment }\end{array}$ \\
\hline $\begin{array}{l}\text { SOLAR-JET } \\
{[42]}\end{array}$ & $\begin{array}{l}\mathrm{CO}_{2}+ \\
\text { water }\end{array}$ & & $\begin{array}{l}\text { EU-project } \\
2011-2015\end{array}$ \\
\hline
\end{tabular}




\subsection{HEFA kerosene}

HEFA is the acronym for Hydrotreated Esters and Fatty Acids, other used denotations are HVO (Hydrotreated Vegetable Oils) [19] and HRJ (Hydroprocessed Renewable Jet) [5]. These names refer to the raw material as well as to the way of converting the feedstock into fuel. The important components are triglycerides [19] forming the base material in any natural fats and oils [44]; triglycerides are belonging to the chemical family of ester; they are derived from glycerol (a poly-alcohol) and three fatty acids. Many different types of a triglyceride exist, with saturated and unsaturated (double bonds) types; an example of a molecular structure of a triglyceride is shown in Fig. 3. Thus, in principle, all kinds of fats and oils may be used for the production of HEFA kerosene, with vegetable oils (eatable or not) as well as oil and fat residues from oil production, cooking, or animal fats $[19,20]$ as main resources, besides others. Vegetable oils are used predominantly due to their better availability [20], with recent developments waste oil as feedstock becomes more important. Of course, depending on the source, a different pre-treatment is necessary [19].

In general, independent of the raw material, the HEFA fuel production, also shown in Fig. 4, comprises the following four steps $[19,20]$ :

1) Refinement. Refined oil is required for the conversion. Vegetable oil has to be extracted from oil plants, e.g. via a classical oil press, whereas used cooking oil or other residues afford a suitable purification process depending on the kind of impurity.

2) Deoxygenation and hydrogenation. The refined oil is transformed to pure hydrocarbons by reaction with hydrogen at about $325^{\circ} \mathrm{C}$ and 50 bar [28]. Thus, oxygen (not allowed to be a component in a jet fuel according to the specification) is removed from the triglyceride molecule; at the same time, unsaturated bonds are hydrogenated resulting in molecules with linear hydrocarbon chains consisting of $\mathrm{C}$ - and $\mathrm{H}$-atoms only, thus containing no $\mathrm{O}$ atoms any more.

3) Cracking and isomerization. Since the length (size) and the degree of branching of hydrocarbons have a considerable influence on physical and chemical properties, molecules with a very long hydrocarbon chain have to undergo a cracking reaction yielding to smaller hydrocarbons in order to be in accordance with the specification, for e.g. cold flow properties. This step can run together with an isomerization step to yield branched hydrocarbons.

4) Distillation. At the end, there are two separation steps: (i) water and gaseous components are removed; and (ii) distillation yielding the final products, a mixture of naphtha, kerosene, and diesel.

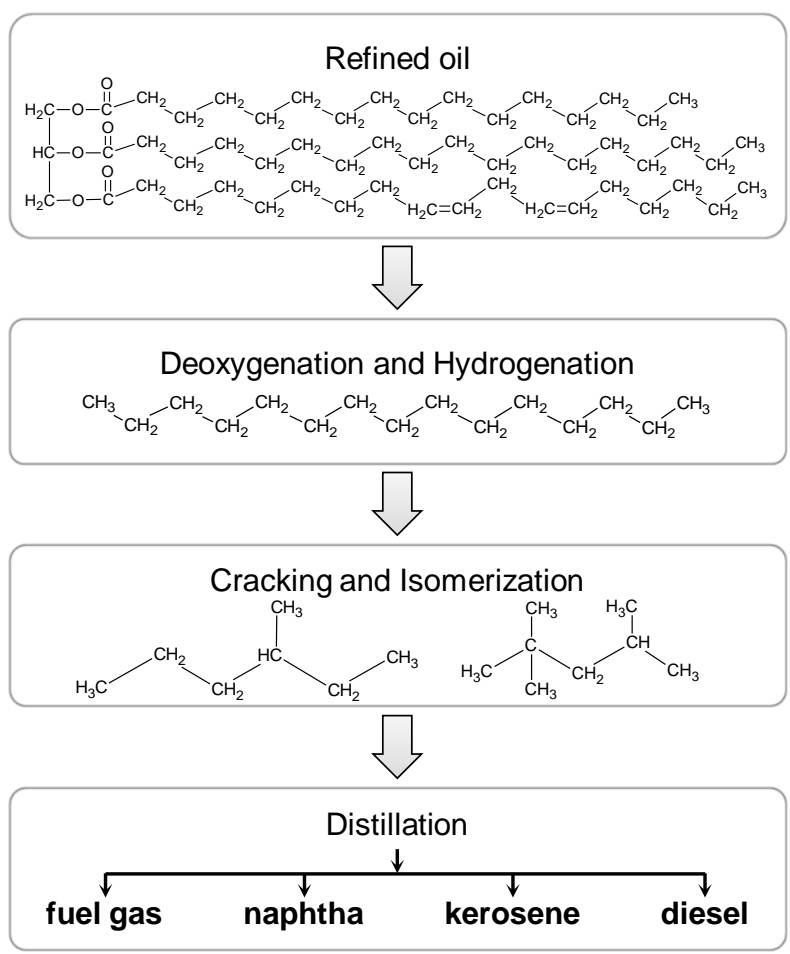

Fig. 4 Important process steps for the production of HEFA fuels

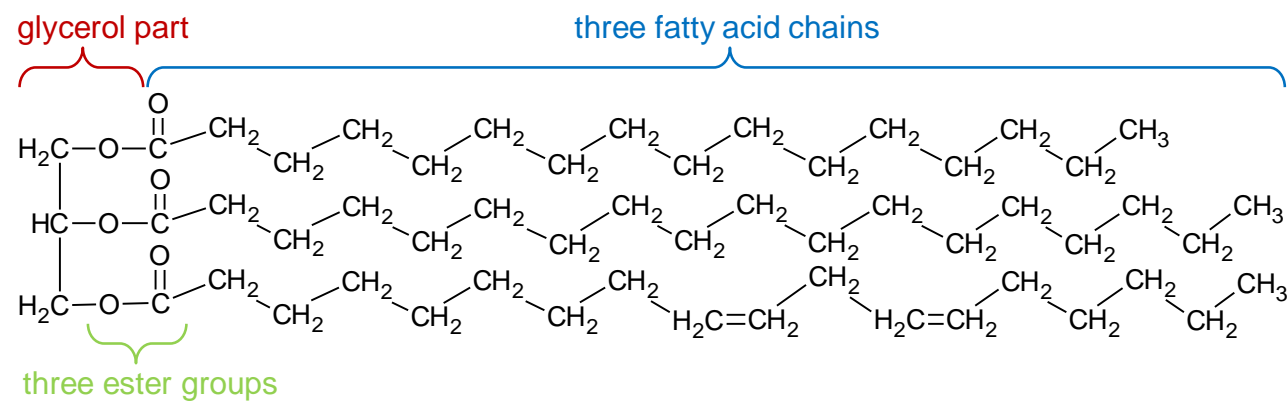

Fig. 3 Typical structure of a triglyceride as it can be found in natural fats and oils, the ester groups are formed by the reaction of glycerol with fatty acids 
Similar to the FT-SPK fuel, the HEFA-kerosene has been approved as a blending component up to 50 vol.- $\%$ in crude-oil kerosene, mostly because HEFA, besides other fuel characteristics like cold flow properties, contains no aromatics [19] needed to fulfil the specification $[5,19]$.

Several companies producing HEFA fuels have been established, as summarized in Table 2. Most of them are producing diesel as main product in their bio-refineries; for example, Neste [45], the biggest producer of HEFA, uses waste and residues as well as vegetable oils as raw material [46]. Both kinds of feedstock are also used by the Renewable Energy Group Inc. (REG) [47]. Neste has refineries at three different facilities (Porvoo, Rotterdam, and Singapore); they can achieve a total production capacity of 2.6 million tons per year [48], with the refineries at Rotterdam and Singapore each has a capacity of one million tons $[49,50]$. REG operates several refineries in North America, the biggest one with a nominal capacity of 100 million gallon per year [51] (approx. 0.3 million tons).

Table 2 List of HEFA fuel producing companies

\begin{tabular}{|c|c|c|c|}
\hline Company & Feedstock & $\begin{array}{c}\text { Capacity } \\
\text { (t/a) }\end{array}$ & Comment \\
\hline Neste [48] & $\begin{array}{l}\text { waste, residues, } \\
\text { vegetable oils }\end{array}$ & $\begin{array}{l}2.6 \text { million } \\
\text { total }\end{array}$ & $\begin{array}{l}\text { diesel } \\
\text { mainly }\end{array}$ \\
\hline REG [47] & $\begin{array}{l}\text { waste, residues, } \\
\text { vegetable oils }\end{array}$ & $\begin{array}{l}1.6 \text { million } \\
\text { total }[65]\end{array}$ & diesel only \\
\hline $\begin{array}{l}\text { AltAir } \\
\text { Fuels [53] }\end{array}$ & $\begin{array}{l}\text { inedible agri- } \\
\text { culture waste } \\
\text { fats and oils }\end{array}$ & $\begin{array}{l}0.13 \text { million } \\
\text { approx. }\end{array}$ & jet + diesel \\
\hline $\begin{array}{l}\text { Petrixo } \\
\text { Oil \& Gas } \\
{[54,55]}\end{array}$ & & $\begin{array}{l}0.5 \text { million } \\
{[55]}\end{array}$ & $\begin{array}{l}\text { several fuels, } \\
\text { starting } 2017\end{array}$ \\
\hline Eni [56] & palm oil & $\begin{array}{l}0.315 \text { million } \\
{[61]}\end{array}$ & $\begin{array}{l}\text { several fuels, } \\
\text { mix }\end{array}$ \\
\hline $\begin{array}{l}\text { Diamond } \\
\text { Green } \\
\text { Diesel } \\
{[57]}\end{array}$ & $\begin{array}{l}\text { animal fats, } \\
\text { used cooking } \\
\text { oil }\end{array}$ & $\begin{array}{l}0.45 \text { million } \\
\text { approx. }\end{array}$ & $\begin{array}{l}\text { diesel } \\
\text { only }\end{array}$ \\
\hline Total [59] & $\begin{array}{l}\text { used oils, vege- } \\
\text { table oils }\end{array}$ & 0.5 million & $\begin{array}{l}\text { diesel } \\
\text { mainly, } \\
\text { starting } 2018\end{array}$ \\
\hline $\begin{array}{l}\text { Solazyme } \\
{[60]}\end{array}$ & $\begin{array}{l}\text { oil from micro- } \\
\text { algae }\end{array}$ & $\begin{array}{l}0.1 \text { million } \\
{[61]}\end{array}$ & $\begin{array}{l}\text { information } \\
\text { not available }\end{array}$ \\
\hline
\end{tabular}

By using the UOP Renewable Jet Fuel Process [52], AltAir Fuels LLC and Petrixo Oil \& Gas LLC concentrate on producing renewable jet fuel, besides the common biodiesel production.
Since early 2016, AltAir is able to produce biofuel in a modified petroleum refinery of a capacity of 42 million gallons per year [53] (approximately 0.13 million tons). Petrixo is building a new bio-refinery designed to produce about 0.5 million tons of different kinds of biofuels per year $[54,55]$. Unfortunately, there is no information available about the current progress of the operating status of this facility. Technology from Honeywell-Universal Oil Prodcuts (UOP) LLC is also exploited by the companies Eni S.p.A. and Diamond Green Diesel LLC who are more focusing on producing diesel and other fuels [5658] than synthetic jet fuels. Also concentrating on the production of biodiesel, Total is building a new biodiesel plant in France of a capacity of 0.5 million tons, expected to become operational in 2018 [59]. In addition, Total supports the research on cultivating micro algae stems [18] that create a kind of vegetable oil. On the other hand, Solazyme Inc. is already able to produce fuels based on microalgae [60], with a capacity of about 100,000 tons jet fuel per year [61].

Up to now, HEFA was the most frequently used biofuel in aviation [62], often supplied by SkyNRG BV being the leader in the distribution of sustainable jet fuels $[63,64]$.

\subsection{Farnesane}

In contrast to FT- and HEFA-fuels, farnesane, also called 2,6,10-trimethyldodecane, is a single component fuel since it consists only of a single molecule, a threefold branched long-chained alkane, $\mathrm{C}_{15} \mathrm{H}_{32}$, with its structure shown in the bottom box of Fig. 5. Besides farnesane, two more synonyms for this type of biofuels exist: SIP (Synthesized Iso-Paraffins, from hydroprocessed fermented sugars), and DSHC (Direct Sugar to Hydrocarbons), respectively [19].

Sugar is the feedstock for the farnesane production; hence, it is - in principle - also possible to use lignocellulose mainly built up from sugar molecules as raw material [20].

The farnesane production process, illustrated in Fig. 5, consists of three steps [19]:

1) Farnesene production. At first, farnesene - the farnesane precursor molecule - is produced by yeast in a fermentation process. The yeast is genetically modified in such a way that sugar is transformed into hydrocarbons (primary farnesene), instead of ethanol [20, 66, 67].

2) Hydrogenation. The farnesene molecule is an unsaturated molecule with 4 double bonds, $\mathrm{C}_{15} \mathrm{H}_{24}$, belonging to the class of terpenes occurring in essential oils extracting from plants [68]. Thus, for the use as aviation fuel, it must be hydrogenated to avoid poor storage stability due to the high reactivity of the double bonds. This hydrogenation step results in the target molecule farnesane.

3) Purification and Distillation. In the final step, farnesane is purified by distillation.

Farnesane, developed by Amyris Inc. with support from Total, is approved for blending with conventional 
Jet A-1 up to $10 \%[19,67,69]$, due to the fact it is a pure component (see [19] for details). The production site for farnesene, the farnesane precursor, in Brotas (Brazil), having a capacity of about 30 million liters per year [69], was acquired in November 2017 from the Dutch company DSM [70, 71]. Indeed, farnesene is not only converted to farnesane but also to other products (e.g. solvents, polymers, emollients and vitamins) [66].

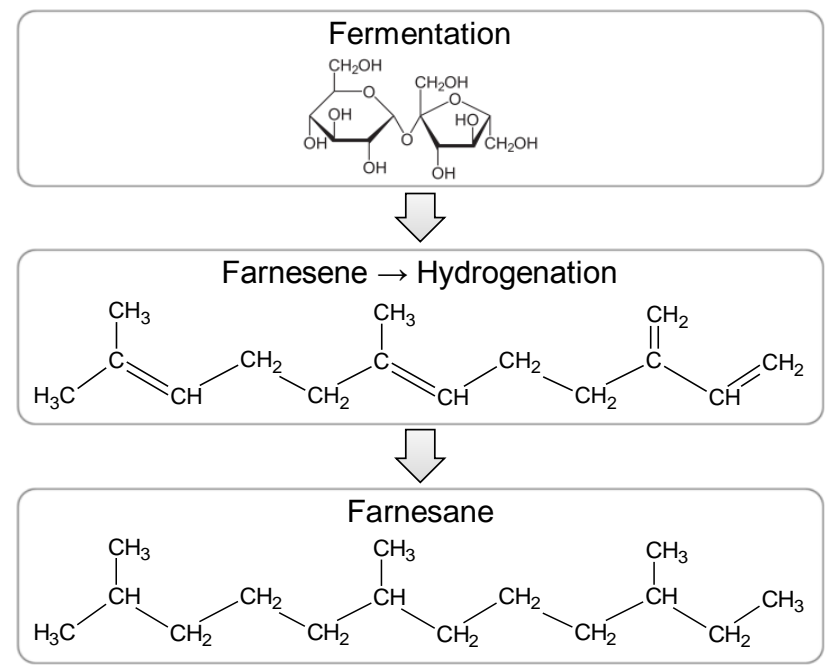

Fig. 5 Process steps for the production of farnesane

\subsection{Alcohol-to-Jet}

The name Alcohol-to-Jet, also well-known as AtJ, shows that this type of alternative aviation fuel is made from alcohols.

Alcohols themselves can be produced by several chemical syntheses, however, not necessarily sustainable. Currently, the best known biotechnological production process for alcohols (at least for ethanol) is the fermentation of sugars by yeasts, a long-standing and established route. Similarly, starch, which is build up from sugar molecules, can be used directly as input material for fermentation. Since sugar molecules are also the basic elements of cellulose and hemicellulose, being two main components of lignocellulose, a further alternative in the use of lignocellulosic materials as feedstock exists [20]. A slightly different fermentation process was developed by LanzaTech Ltd. who uses carbon rich gases $\left(\mathrm{CO}+\mathrm{CO}_{2}+\right.$ $\mathrm{H}_{2}$ ) from gasification or industrial waste gases as substrate for the fermentative ethanol production [19, 72].

For the AtJ-production, not only ethanol is used as feedstock but also further small alcohols with up to five carbon atoms; the following process description (Fig. 6) is similar for all kinds of alcohols [19, 20]:

1) Dehydration. Water is split off from the alcohol molecule by dehydration leading to alkenes as shown exemplarily for isobutanol in Fig. 6a). Water and other impurities have to be removed from the reaction mixture.

2) Oligomerisation. Larger molecules are synthesized from the alkenes occurring in the gas phase. This type of reaction is called oligomerisation; an example for this type of reaction is given in Fig. 6b).

3) Hydrogenation. Oligomers which are in the jet fuel range depending on the number of carbon atoms (chain length), are first separated and then saturated with hydrogen, to convert all still existing double bonds into single bonds in order to fulfil the jet fuel specifications.

4) Distillation. To get a pure jet fuel, distillation as last process step is necessary.

$$
\begin{aligned}
& \text { a) }{ }_{\mathrm{H}_{3} \mathrm{C}^{\prime}}^{\mathrm{H}_{3} \mathrm{C}} \mathrm{CH}-\mathrm{CH}_{2}-\mathrm{OH} \underset{-\mathrm{H}_{2} \mathrm{O}}{\stackrel{\mathrm{H}_{3} \mathrm{C}^{\prime}}{\mathrm{C}}} \stackrel{\mathrm{H}_{3} \mathrm{C}}{\mathrm{C}} \mathrm{CH}_{2} \\
& \text { b) }
\end{aligned}
$$

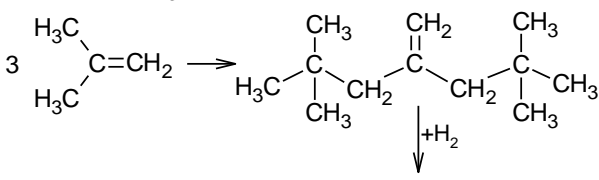

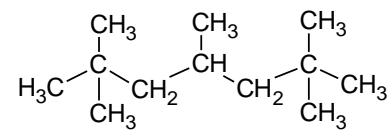

Fig. 6 a) - Dehydration of isobutanol leading to the corresponding alkene isobutene, b) - Oligomerisation of several isobutene molecules forming a larger molecule, c) - Hydrogenation of double bonds to yield a saturated product containing in an AtJSPK fuel

This type of AtJ-fuel consists, due to the production process, mainly of branched hydrocarbons (isoparaffins) similar to the FT-SPK composition. However, the variety in the composition of a specific AtJ-SPK is much less which is a reason why it has been approved for blending with crude-oil kerosene up to 30 vol.-\% only [73]. This approval is only valid for the AtJ-production from isobutanol [22] as developed and performed by Gevo Inc.; note that Gevo has also designed and demonstrated a technology using residual wood as feedstock [14]. Similar to Amyris for the farnesene production, Gevo has manipulated the metabolism of yeast so that the microorganisms produce isobutanol instead of ethanol during the fermentation [74]. Gevo has committed its goal to achieve a product volume of at least 750,000 gallons isobutanol in 2016 [75] (approx. 2,288 t/a); however, the input capacity for isobutanol of their bio-refinery, where - besides jet fuel - other hydrocarbons are produced, is between 5,000 and 10,000 gallons per month [76] (approx. 183-366 t/a).

Byogy Renewables Inc. and Swedish Biofuels AB, working together with LanzaTech, are two further AtJfuel producing companies as listed in Table 3. Both are using mainly ethanol as feedstock and focus on a fuel production which contains aromatics, too, yielding a jet fuel named AtJ-SKA (Alcohol-to-Jet synthetic kerosene with aromatics) $[20,77,78]$. 
Table 3 Overview on companies producing AtJ (Alcohol-to-Jet) fuel

\begin{tabular}{llll}
\hline Company & $\begin{array}{c}\text { Alcohol as } \\
\text { feedstock }\end{array}$ & \multicolumn{1}{c}{ Capacity } & Product \\
\hline Gevo [74] & isobutanol & $\begin{array}{c}\text { up to 366 t/a } \\
\text { approx. input }\end{array}$ & AtJ-SPK \\
& ethanol & $\begin{array}{l}\text { AtJ-SKA } \\
{[20]}\end{array}$ \\
Byogy [77] & & AtJ-SKA \\
& $\mathrm{C}_{2}-\mathrm{C}_{5}$ & {$[20]$} \\
Swedish & alcohols & \\
\hline
\end{tabular}

\subsection{Other alternative fuels}

Besides the approved alternative aviation fuels presented so far, there are several other fuels under intense investigation. These are kerosenes made by catalytic hydrothermolysis (CH-kerosene), the hydroprocessed depolymerized cellulosic jet fuel (HDCJ-kerosene), and the hydrodeoxygenated synthesized kerosene (HDO-SK), which also can be produced as a fuel consisting only of aromatics (HDO-SKA) [19].

$\mathrm{CH}$-kerosene is produced by ARA and traded under the name ReadiJet ${ }^{\circledR}$. It is made from fats and oils, and contains between $10 \%$ and $20 \%$ aromatics; so, it could be used directly as fuel without blending $[19,79]$.

Lignocellulosic material is the feedstock for the other two synthetic fuels, with sugar to be used for the HDOSK fuels as well (due to the use of sugar as feedstock it is possible to name the product as DSHC-fuel [20]). Apart from the thermal decomposition of large lignocellulosic molecules, especially during the HDCJ-process, all these alternative fuels are formed in catalytic processes with hydrogen involved $[19,20]$. The process used for HDO$\mathrm{SK}(\mathrm{A})$ production is called BioForming ${ }^{\circledR}$ and was developed by Virent Inc. [19, 20, 80]. Unfortunately, the biggest producer of HDCJ-kerosene, KiOR Inc., went bankrupt in 2014 [19,81]; similar technologies were developed and designed by Licella [82] and Honeywell UOP $[83,84]$.

\section{Combustion properties}

As fundamental combustion properties, the laminar burning velocity and the ignition delay time both characterize the global combustion behaviour of any fuel; in addition, they are used for the validation and improvement of reaction mechanisms [85-88], which are developed to describe and predict the combustion of fuels. In the following section, an overview on the measurement of these combustion properties will be given for several alternative aviation fuels; in addition, a comparison with data for a conventional Jet A-1 fuel made from crude oil will be presented. The synthetic fuels considered are represented by the fossil-based fuels GtL and CtL, and by the biofuels farnesane and AtJ-SPK. The CtL- and GtL-fuels were studied within the framework of the EU-project
ALFA-BIRD [85-89]. Although both are FT-fuels, they differ considerably in their composition: GtL is a synthetic paraffinic kerosene (SPK), whereas CtL contains aromatic compounds [21, 85-88].

\subsection{Laminar burning velocity}

The laminar burning velocity can be considered as a fundamental quantity for the flame propagation of a fuel and, thus, for its reactivity. More precisely, it is defined as the propagation velocity of the flame front into an unburned gas mixture. For a stable flame, equilibrium between the flow rate of the unburned gas and the propagation velocity of the flame front is required.

Using the cone angle method, values of the laminar burning velocity, $S_{\mathrm{u}}$, can be determined according to Equation (1). The cone angle $\alpha$ is measured affording a premixed conical shaped flame [90] as illustrated in Fig. 7. The laminar burning velocity depends on preheat temperature, pressure, and the fuel-air equivalence ratio $(\varphi)$.

$$
S_{\mathrm{u}}=v_{\mathrm{u}} \cdot \sin \alpha
$$

In the present work, experiments were carried out at constant pressures ( 1 bar and 3 bar) and preheat temperature $\left(200^{\circ} \mathrm{C}\right)$, while $\varphi$ is changed during the measurements.
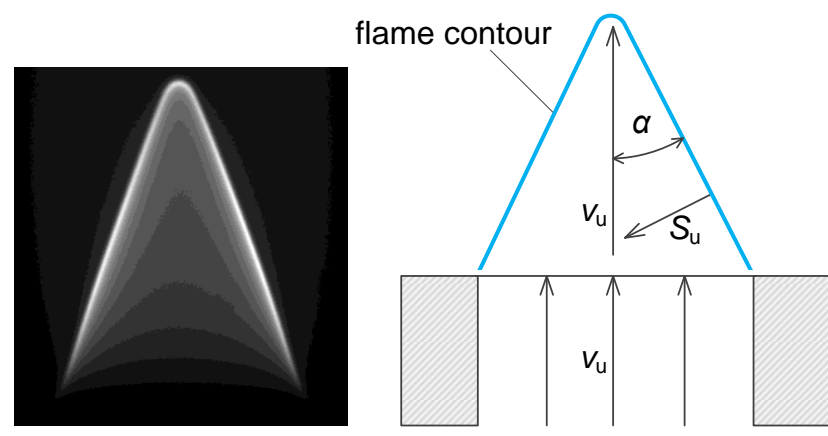

fuel-air-mixture

Fig. 7 Example of a laminar conical flame (left) and a schematic for the determination of the burning velocity (right) $\left(S_{\mathrm{u}}-\right.$ laminar burning velocity, $v_{\mathrm{u}}$ - gas velocity of the unburnt gas mixture, $\alpha$-cone angle determined in the experiment)

Figure 8 shows the comparison between the measured laminar burning velocities for the four different alternative jet fuels and crude-oil made Jet A-1. As expected, the burning velocity reduces with increasing pressure, especially at lean $(\varphi=0.7)$ up to slightly rich $(\varphi=1.3)$ equivalence ratios. Moreover, comparing the different fuels, it is visible that both types of biofuels (AtJ-SPK and farnesane) show almost identical results as the conventional fuel; furthermore, the FT-fuels are likewise very close to each other. Since AtJ-SPK, farnesane, and GtL consist mainly of branched alkanes, similar values of the burning velocities for the alternative fuels are expected as the reaction behaviour depends on the molecular structure of the fuels. Looking somewhat more detailed at the results 
in Fig. 8, AtJ-SPK has slightly smaller burning velocities than the other fuels, particularly at $p=3$ bar. The reason might be that highly branched molecules are less reactive than molecules with a linear or only slightly branched structure. Comparing the structure of AtJ-SPK molecules (for example, see the lower molecular structure in Fig. 6) with the one of farnesane (Fig. 5) or of a GtL fuel, being a multicomponent mixture with different branched molecules, it is obvious that the AtJ-SPK fuel has a higher degree of branching.

Concerning the results for Jet A-1 it is important to know that a jet fuel contains up to four different types of molecules, namely linear (unbranched), branched, and cyclic alkanes (all are saturated hydrocarbons with single bonds only) as well as aromatics [91]. The composition of a conventional jet fuel can vary within certain limits; the specification affords a maximum content of aromatics limited to 25 vol.- $\%$ (a minimum of 8 vol.- $\%$ is only required when blending with alternative fuels) [19]. A change in the composition may also cause small changes of the laminar burning velocity. That is also to notice for the FT-fuels since GtL, as mentioned above, as well as $\mathrm{CtL}$ consist of numerous different components.

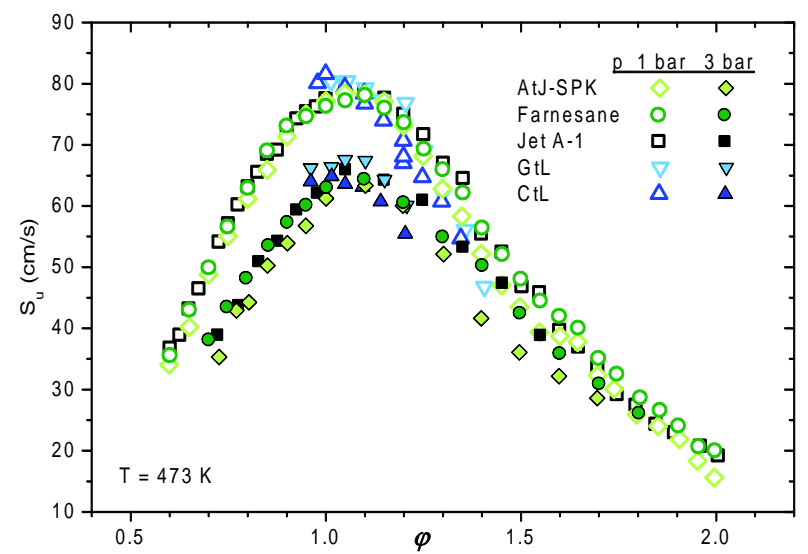

Fig. 8 Laminar burning velocity $\left(S_{\mathrm{u}}\right)$ for different alternative (synthetic) jet fuels and Jet A-1 measured as a function of the fuel-air equivalence ratio $(\varphi)$

\subsection{Ignition delay time}

The ignition delay time is defined as the time period between the initiation of the reactive system at $t=0 \mu \mathrm{s}$ and the onset of ignition [88] (see Fig. 9). The ignition process is characterized by the decomposition of (large) molecules and the formation of radicals. When the ignition of the fuel-air mixture occurs, a steep increase of excited $\mathrm{CH}^{*}$-radical emission as well as a moderate pressure increase is observed, as illustrated in Fig. 9.

The ignition delay time measurements are performed behind reflected shock waves in a high pressure shock tube $[87,88]$. As illustrated in Fig. 9, the time difference between initiating the reactive system by the reflected shock wave and the peak emission of the $\mathrm{CH}^{*}$-radical, measured at $\lambda=431 \mathrm{~nm}$ at a distance of $10 \mathrm{~mm}$ before the end plate, is determined as a function of the temperature.
Both, the fuel-air equivalence ratio $\varphi$, chosen to $\varphi=0.5,1.0$, and 2.0, and the initial pressure $p$ around 16 bar have an influence on the ignition delay time.

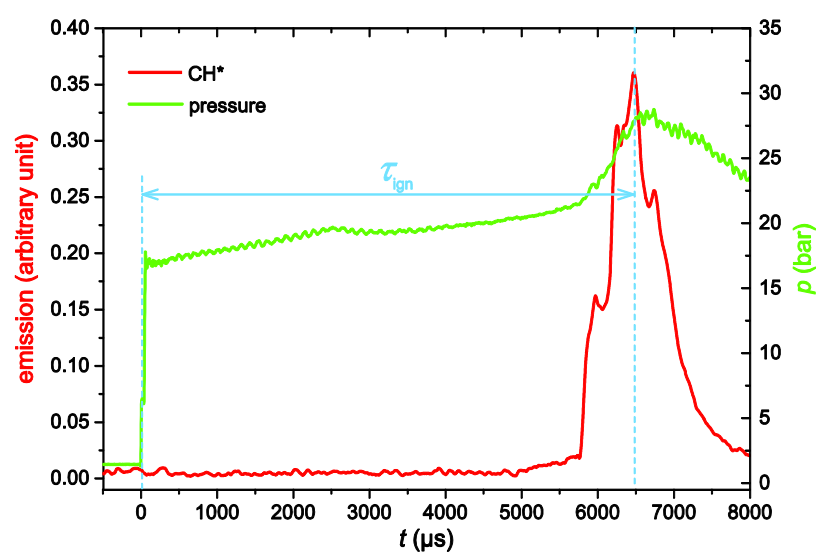

Fig. 9 Ignition delay time measurements of farnesane - synthetic air diluted $1: 2$ in nitrogen at $\varphi=1.0$ and initial conditions of $T=883 \mathrm{~K}$ and $p=16.85$ bar. The ignition delay time $\left(\tau_{\text {ign }}\right)$ is defined as the time difference between the initiation of the reactive system and the maximum of $\mathrm{CH}^{*}$-emission monitored at a distance of $10 \mathrm{~mm}$ before the end plate.

For stoichiometric mixtures (Fig. 10), the ignition delay times of the FT-fuels are found to be more similar to those of Jet A-1 than to those of the biofuels (AtJ-SPK and farnesane). Especially at temperatures higher than $1200 \mathrm{~K}$, AtJ-SPK tends towards longer ignition delay times. On the other side, at temperature lower than $1000 \mathrm{~K}$, all alternative fuels show shorter ignition delay times than Jet A-1. Furthermore, at temperatures lower than $900 \mathrm{~K}$, AtJ-SPK has longer ignition delay times than farnesane and GtL. Together with the results for the measurements at $\varphi=2.0$, presented in Fig. 11, showing also slightly longer ignition delay times for AtJ-SPK over the whole temperature range, this findings support the assumption that AtJ-SPK is less reactive than the other jet fuels studied. In general, the differences between AtJSPK, farnesane, and Jet A-1 at $\varphi=2.0$ are small within the temperature range of this study. This is also true for the measurements performed at $\varphi=0.5$ for $\mathrm{GtL}, \mathrm{CtL}$, and Jet A-1; they show very similar results.

In addition to the comparison of the different fuels at a specific fuel equivalence ratio, the evaluation of the ignition behavior at different $\varphi$-values is of interest, too. It is obvious from Fig. 11 that the ignition delay has a more pronounced temperature dependence at $\varphi=0.5$ than at $\varphi=2.0$, crossing at temperatures between $1050 \mathrm{~K}$ and $1200 \mathrm{~K}$. Whereas at low temperatures, rich fuel-air mixtures are more reactive due to peroxide chemistry, leading to shorter ignition delay times, this behaviour changes with increasing temperature (at about 1100-1200 K), where the chain branching reaction, namely $\mathrm{H}+\mathrm{O}_{2} \rightleftharpoons \mathrm{OH}+\mathrm{O}$, becomes dominant for the formation and propagation of radicals. With more oxygen available in lean fuel-air mixtures, the radical formation reactions 
are more efficient resulting in shorter ignition delay times than in fuel rich mixtures.

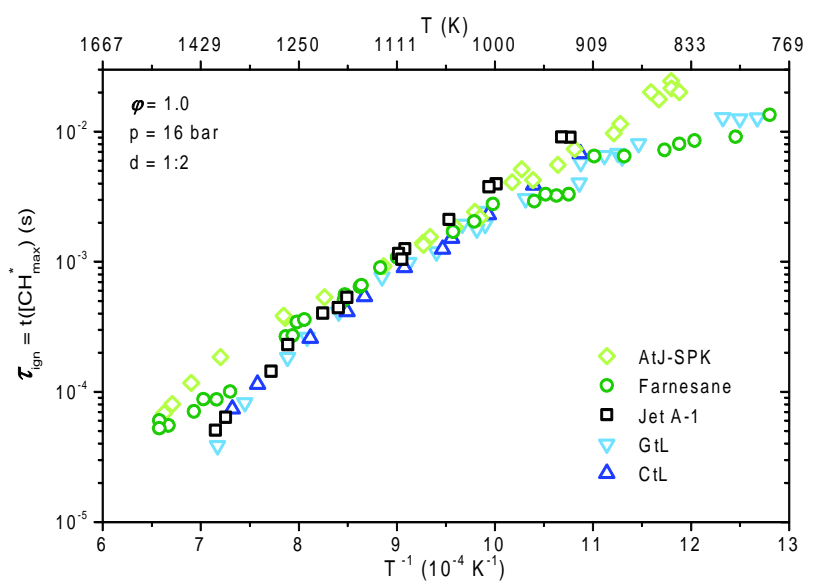

Fig. 10 Ignition delay times $\left(\tau_{\text {ign }}\right)$ of different alternative jet fuels and Jet A-1 at $\varphi=1.0$ measured at an initial pressure around $16 \mathrm{bar}$ as a function of temperature using synthetic air (80 vol-\% $\mathrm{N}_{2}+20$ vol- $\% \mathrm{O}_{2}$ ) as oxidizer and diluted $1: 2$ with $\mathrm{N}_{2}$

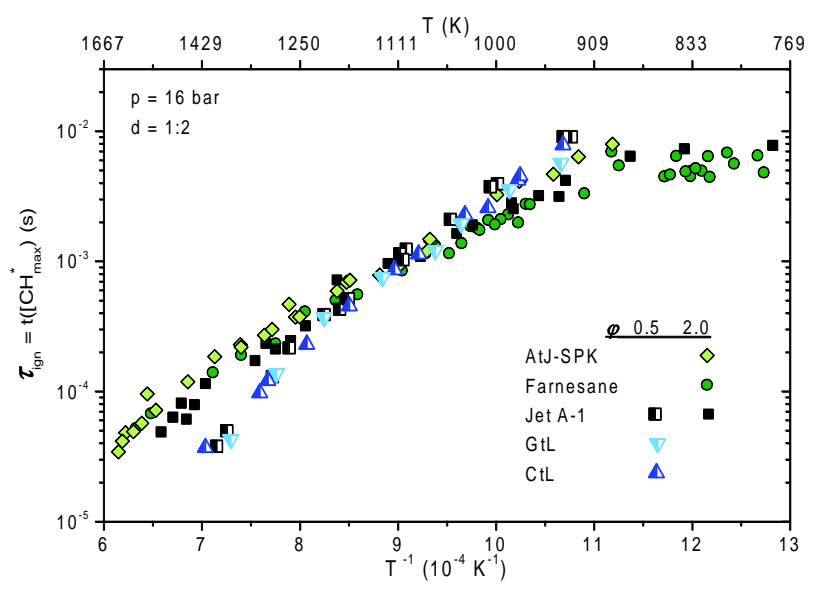

Fig. 11 Ignition delay times $\left(\tau_{\text {ign }}\right)$ of fuel-oxidizer mixtures diluted 1:2 with $\mathrm{N}_{2}$ measured each at about 16 bar as a function of temperature using synthetic air $\left(80\right.$ vol- $\% \mathrm{~N}_{2}+20$ vol- $\left.\% \mathrm{O}_{2}\right)$ as oxidizer: at $\varphi=0.5$ for $\mathrm{CtL}, \mathrm{GtL}$, and Jet A-1 and at $\varphi=2.0$ for AtJ-SPK, farnesane, and Jet A-1.

\section{Challenges}

In the previous chapter, it was shown that within the investigated parameter range the fundamental combustion properties of different kinds of alternative jet fuels have very similar combustion behaviour as conventional Jet A-1. Earlier, the present status of the possibilities for the production of biogenic jet fuels was discussed.

The use of synthetic fuels is directly connected to its global availability, besides other issues such as costs and compatibility with today's airplanes, fuel's logistic, and infrastructure.

Concerning availability, up to now only the FischerTropsch process using coal or natural gas as feedstock exists in an industrial scale [27]. The establishment of a new technology is a hard business - e.g. a promising development was the $\mathrm{CO}_{2}$-to-fuel technology deployed by Joule Unlimited Inc. using microorganisms [92]; but unfortunately, they failed [93].

HEFA fuel is produced at large scale plants by Neste. Due to economic reasons, the common HEFA fuel produced today is diesel [27] caused mainly by the structure of the natural triglyceride molecules: They have carbon chain lengths between $\mathrm{C}_{14}$ and $\mathrm{C}_{20}$ correlating better with the diesel fuel range than with the jet fuel range which contains smaller molecules, mostly between $C_{8}$ and $C_{16}$. Therefore, to avoid additional selective cracking steps needed for the jet fuel production from fats and oils, it would be desirable to exploit oil plants containing triglycerides with appropriate (smaller) carbon chain lengths [94]. Furthermore, this strategy might strengthen the advantage of the HEFA production process due to its low process complexity: The triglycerides are simply broken down into their basic components [20] while in other processes, the biomolecules are almost completely fragmented.

In contrast to HEFA, the molecular size (carbon length) of farnesane and AtJ correlates much better with Jet A-1. However, it might turn out to be a major drawback with respect to the business case: It is more economic to produce an alternative crude fuel mixture of which jet fuel as well as gasoline and diesel can be produced, than to produce jet fuel as single purpose product. At least farnesane is also under investigation as biodiesel [66, 9597]. However, as long as the crude oil price is low (64 US\$/bbl. for Brent oil in November 2017 comparing to about $110 \mathrm{US} \$ / \mathrm{bbl}$. in summer 2014 [99]) a commercial competitiveness to conventional kerosene appears not to be realistic.

In addition to the cheap crude oil, the required amount of alternative bio-jet fuel is missing to enter market competition. Over more, besides the HEFA process, all bio-jet fuel producing technologies are in pilot or demonstration stage causing higher production costs [20] contributing to the higher price of a biofuel compared to conventional kerosene. That is likewise the case for AtJ-SPK [99] and farnesane, although both are already approved as drop-in fuel. If there is no strong demand for the more expensive bio-jet fuel, e.g. by politics or society, it is foreseen that the biofuel producers will probably have no prospects to expand their production capacity.

The feedstock price affects production costs and fuel price [20] as well. A steady rise in oil prices will increase the prospects of sustainable jet fuels entering the market. The question is open about the origin and the amount of the raw materials needed for processing synthetic fuels. In general, besides municipal waste, many raw materials available in nature are considered as possible fuel candidates, but not all of them are available all year long or at the place where they are needed. Availability is strongly related to the growth period as a consequence of the geographical area. In that sense, woody materials are of advantage because forestry is ongoing yearlong; limits exist for all plant materials associated with agriculture no mat- 
ter whether crop, oil plants or residues. For a continuous production and utilised capacity, the feedstock must be accessible directly at the plant, thus enough storage capacity must be realized. Hence, it must be considered if and how storage time might affect the quality of the raw material. Using natural raw materials means working with heterogeneous material; to cope with a pre-treatment is appropriate to prepare a more uniform material suited for the conversion process.

Another issue regarding the raw material is the competitive situation to the traditional land use and agriculture for food and fodder production as well as to basic raw materials for industry. At the moment, only few amounts of the available biomass trading on the global market can be used without competition [20]. Thus, every kind of waste and residues are predestined as raw material; moreover, this feedstock is assumed to be cheaper than agricultural products. However, it is usually more difficult to treat these (waste and residue) materials because of their more complex structures (e.g. lignocellulose) or their strong inhomogeneity and/or contaminations, in particular, for municipal waste.

In addition to the restricted availability and the potential competition, land use change (LUC) has to be considered for biofuel raw materials produced by farming, such as oil plants, corn, sugar beets or cane. Due to its effect on $\mathrm{CO}_{2}$-emissions (climate change) [5], LUC may contribute to worsen this problem. In this sense, the necessity of LUC is considered to be the decisive factor, not the kind of biomass [94]. Without LUC, the greenhouse gas emissions are estimated to be reduced to about 20-75\% compared to Jet A-1 depending on the raw material as well as on the kind of cultivation and bio-refinery [5, 28].

Besides the feedstock itself, other materials like hydrogen and catalysts are necessary [20] for processing a synthetic jet fuel. When discussing sustainable fuels, the whole production process itself should be sustainable as well. For example, among all bio-jet fuel processes discussed, the HEFA process, the only one established yet, is the one with the highest hydrogen consumption. Unfortunately, at present, the production of hydrogen results almost exclusively from petrochemical processes, to about $90 \%$ [100]: Hydrogen can be provided by conversion of side products generated using steam reforming, yielding additional $\mathrm{CO}_{2}$-emissions [20]. A sustainable $\mathrm{H}_{2}$ production would be $e . g$. the generation by electrolysis of water or steam using excess wind or solar energy; this process is expected to become more relevant in future.

\section{Conclusions}

Today, several technologies are available for the production of sustainable synthetic jet fuels. The most promising are the Fischer-Tropsch and HEFA fuels because large scale plants already exist. But to establish an economically viable bio-jet fuel production, much further progress is needed: Whereas the implementation of biomass feedstock in the FT-process is still missing, the HEFA process is currently more economic for the produc- tion of diesel fuel. More recently, innovative processes and technologies are aiming to yield a bio-aviation fuel; see for example the production of farnesane or AtJ-SPK. As well as for FT-fuels and HEFA, both discussed bio-jet fuels have already been certified as drop-in-fuels although they are approved with a lower maximum percentage: $10 \%$ for farnesane and $30 \%$ for AtJ-SPK respectively compared to by $50 \%$ for the FT- and HEFA-fuels.

In addition, for the assessment of the combustion behaviour of different alternative fuels, experimental investigations of fundamental combustion properties - burning velocity and ignition delay time, which are among the most important combustion properties of any fuel - were presented. For farnesane, these data were reported for the first time, to the best of our knowledge. It was observed that only AtJ-SPK seems to have a lower reactivity than the other fuels considered due to his highly branched structure. However the deviations are small, so overall it can be summarized that all investigated fuels, farnesane and AtJ-SPK (both are sustainable) as well as CtL and GtL (made from fossil sources), show a similar combustion behaviour within the considered parameter range as Jet A-1, being the conventional crude oil based jet fuel available worldwide.

\section{Acknowledgement}

The authors thank A. Zschocke from Deutsche Lufthansa AG, S. Scheuermann and J. Ortner from the Bundeswehr Research Institute for Materials, Fuels and Lubricants (WIWeB) in Erding (Germany) for suppling us with farnesane and AtJ-SPK. Furthermore, we thank our colleagues from DLR Stuttgart: N. Ackermann, J. Herzler (now Univ. Duisburg-Essen), Capt. L. Thomas (USAF), Ph. Coens, and H. Dreyer for assisting us in measuring the ignition delay times as well as J. Herbst, Th. Kick and M. B. Raida for assisting us in measuring the laminar burning velocities. Some parts of the measurements were performed within the EU project ALFABIRD (EUFP7/2007-2013, grant agreement no ${ }^{\circ} 213266$ ) and the EU-tender SWAFEA (service contract No. Tren/F2/408.2008/SI2.518403/SI2.519012).

\section{Literature}

1. Lee D. S., Fahey D.W., Forster P. M., Newton P. J., Wit R. C. N.: Aviation and global climate change in the 21st century. Atoms. Environ. 43(22-23), 3520 3537 (2009)

2. Blakey S., Rye L., Wilson C.W.: Aviation gas turbine alternative fuels: A review. Proc. Comb. Inst. 33(2), 2863-2885 (2011)

3. Braun-Unkhoff M., Riedel U., Wahl C.: About the Emissions of Alternative Jet Fuels. CEAS Aeronaut. J. 8(1), 167-180 (2016)

4. European Commission: 2 million tons per year: A performing biofuels supply chain for EU aviation. https://ec.europa.eu/energy/sites/ener/files/20130911 _a_performing_biofuels_supply_chain.pdf (2013). 
Accessed 28 November 2017

5. Wang W.-C., Tao L.: Bio-jet fuel conversion technologies. Renew. Sust. Energ. Rev. 53, 801-822 (2016)

6. SkyNRG: Track record - SAF flights. http://skynrg.com/saf-flights/. Accessed 28 November 2017

7. IATA: Fact Sheet - Alternative Fuels. http://www.iata.org/pressroom/facts_figures/fact_she ets/Documents/fact-sheet-alternative-fuels.pdf (2017). Accessed 28 November 2017

8. CAAFI: SAJF offtake agreements. http://www.caafi.org/activities/pdf/Airline_Offtake_S lides_Oct2017.pdf (2017). Accessed 28 November 2017

9. Gevo: News Release - On Fly Green Day, Eight Airlines Fly with Gevo's Jet Fuel from O'Hare. http://ir.gevo.com/phoenix.zhtml?c=238618\&p=irolnewsArticle\&ID=2315423 (2017). Accessed 28 November 2017

10. Lane J.: 9 Fly with Gevo's Jet Fuel from O'Hare on "Fly Green Day". Biofuels Digest. http://www.biofuelsdigest.com/bdigest/2017/11/08/9fly-with-gevos-jet-fuel-from-ohare-on-fly-green-day/ (2017). Accessed 28 November 2017

11. United Airlines: Alternative fuels. https://www.united.com/web/en-

US/content/company/globalcitizenship/environment/a lternative-fuels.aspx (2017). Accessed 28 November 2017

12. Lufthansa Group: Sustainable alternative fuels https://www.lufthansagroup.com/en/responsibility/cli mate-and-environmental-responsibility/fuelconsumption-and-emissions/alternative-fuels.html (2017). Accessed 28 November 2017

13. SkyNRG: SkyNRG corporate program. http://skynrg.com/klmcorporatebiofuelprogramme.

Accessed 28 November 2017

14. Nara: Forest-powered flight heads to Washington, D.C. https://nararenewables.org/2016/11/15/forestpowered-flight-heads-to-washington-d-c/ (2016). Accessed 28 November 2017

15. Cathay Pacific: Sustainable fuels. http://downloads.cathaypacific.com/cx/aboutus/sd/20 16/climate-change/sustainable-fuels/index.html (2016). Accessed 28 November 2017

16. Zaimes G., Borkowski M., Khanna V.: Life-Cycle Environmental Impacts of Biofuels and Co-products. In: Gupta V.K., Tuohy M.G. (eds.) Biofuel Technologies - Recent Developments, pp. 473-477., Springer, Berlin, Heidelberg (2013)

17. EUALGAE: The European network for AlgalBioproducts. http://eualgae.eu/ (2017). Accessed 28 November 2017

18. Total: From microalgae to molecules of interest: focus on AlgaePARC. https://www.total.com/en/energyexpertise/projects/bioenergies/algaeparc. Accessed 28 November 2017

19. Zschocke A., Scheuermann S., Ortner J.: High Biofu- el Blends in Aviation (HBBA). http://www.hbba.eu (2015). Accessed 28 November 2017

20. Neuling U., Kaltschmitt M.: Conversion routes for production of biokerosene - status and assessment. Biomass Conv. Bioref. 5, 367-385 (2015)

21. Braun-Unkhoff M., Riedel U.: Alternative fuels in aviation. CEAS Aeronaut. J. 6(1), 83-93 (2015)

22. FAA Aviation Safety: Engine Fuel and Control Semi-Sythetic Jet Fuel, SAIB: NE-11-56R2. http://caa.gov.il/index.php?option=com_docman\&vie $\mathrm{w}=$ download\&alias=5996-engine-fuel-and-controlsemi-synthetic-jet-fuel-19-052016\&category slug $=2016-$ 1\&Itemid=669\&lang=he.pdf (2016). Accessed 28 November 2017

23. FAA: New Alternative Jet Fuel Approved. http://www.faa.gov/news/updates/?newsId=85425 (2016). Accessed 28 November 2017

24. Schulz H: Short history and present trend of FischerTropsch synthesis. Applied Catalysis A: General 186, 3-12 (1999)

25. Sasol: About Sasol - Southern African Operations Overview. http://www.sasol.com/aboutsasol/regional-operating-hubs/southern-africaoperations/secunda-synfuels-operations/overview. Accessed 28 November 2017

26. Shell: Gas-to-Liquids. http://www.shell.com/energyand-innovation/natural-gas/gas-to-liquids.html. Accessed 28 November 2017

27. Hu J., Yu F., Lu Y.: Application of Fischer-Tropsch Sythesis in Biomass to Liquid Conversion. Catalysts 2, 303-326 (2012)

28. Zschocke A.: Abschlussbericht zu dem Vorhaben Projekt BurnFAIR - Arbeitspakete 1.1 bis 1.4. (2014)

29. de Klerk A.: Synthesis Gas Production, Cleaning and Conditioning. In: Fischer-Tropsch Refining, pp. 5172. Wiley-VCH, Weinheim (2011)

30. de Klerk A.: Fischer-Tropsch Synthesis. In: FischerTropsch Refining, pp. 73-103. Wiley-VCH, Weinheim (2011)

31. de Klerk A.: Jet Fuel Refining. In: Fischer-Tropsch Refining, pp. 541-558. Wiley-VCH, Weinheim (2011)

32. de Klerk A.: Fischer-Tropsch Facilities at a Glance. In: Fischer-Tropsch Refining, pp. 3-20. Wiley-VCH, Weinheim (2011)

33. CAAFI: Alternative Jet Fuel - Frequently Asked Questions. http://www.caafi.org/resources/faq.html\#Alternative (2016). Accessed 28 November 2017

34. Red Rock Biofuels: Technology http://redrockbio.com/Technology.html. Accessed 28 November 2017

35. Sasol: Annual integrated report. http://www.sasol.com/sites/sasol/files/Sasol\%20AIR \%202014\%20complete.pdf (2014). Accessed 28 November 2017

36. Ogleby G.: FedEx plans to deliver 'future of aviation' with biofuels drive. edie.net. 
http://www.edie.net/news/7/FedEx-commits-tofuture-of-aviation-fuel/ (2016). Accessed 28 November 2017

37. Total: BioTfuel: Developing second-generation biofuels. $\quad$ http://www.total.com/en/energyexpertise/projects/bioenergies/biotfuel-convertingplant-wastes-into-fuel (2017). Accessed 28 November 2017

38. Fulcrum Bioenergy: Company - Projects. http://fulcrum-bioenergy.com/company/projects/ (2017). Accessed 28 November 2017

39. SOLAR-JET: Sunlight to jet fuel: European collaboration SOLAR-JET for the first time demonstrate the entire production path of "solar" kerosene. http://www.dlr.de/dlr/Portaldata/1/Resources/docume nts/2014/SOLAR-

JET PR April_2014_R1_0_ENGLISH_final.pdf (2014). Accessed 28 November 2017

40. Weber L.: Diesel aus CO2 - Klare Brühe für die Ministerin. FAZ.net. http://www.faz.net/aktuell/technik-motor/umwelttechnik/johanna-wankas-audi-a8-wird-mitkuenstlichem-diesel-betankt-13547499.html (2015). Accessed 28 November 2017

41. DLR: SOLAR-JET - research group first to produce alternative kerosene using sunlight, water and carbon dioxide.

http://www.dlr.de/dlr/en/desktopdefault.aspx/tabid10081/151_read-10119/\#/gallery/14468 (2014). Accessed 28 November 2017

42. SOLAR-JET: Scientific Approach. http://www.solarjet.aero/page/about-solar-jet/scientific-approach.php (2014). Accessed 28 November 2017

43. Sunfire: Building bridge between energy networks. http://www.sunfire.de/en/applications/fuel (2016). Accessed 28 November 2017

44. RÖMPP: Triacylglycerole. Georg Thieme, Stuttgart (2008)

45. Neste Oil: Neste Oil claims world leadership in biofuels from waste, residue. Biodiesel Magazine. http://www.biodieselmagazine.com/articles/324835/n este-oil-claims-world-leadership-in-biofuels-fromwaste-residue (2015). Accessed 28 November 2017

46. Neste: Renewable raw materials. https://www.neste.com/fi/en/companies/products/rene wable-products/raw-materials. Accessed 28 November 2017

47. Renewable Energy Group: Biodiesel Technologies. http://www.regi.com/technologies/biodiesel. Accessed 28 November 2017

48. Neste:

Renewable

Products.

https://www.neste.com/en/corporate-info/who-weare/business-areas/renewable-products. Accessed 28 November 2017

49. Neste:

Rotterdam refinery https://www.neste.com/en/corporate-info/who-weare/production/rotterdam-refinery. Accessed 28 November 2017

50. Neste:

Singapore

refinery https://www.neste.com/en/corporate-info/who-weare/production/singapore-refinery. Accessed 28 November 2017

51. Renewable Energy Group: REG Grays Harbor, LLC. http://www.regi.com/aboutreg/locations/biorefineries/production-mode/reggrays-harbor-llc. Accessed 28 November 2017

52. Honeywell UOP: Honeywell Green Jet FuelTM. http://www.uop.com/processingsolutions/renewables/green-jet-fuel. Accessed 28 November 2017

53. Lane J.: Renewable jet fuel, competitive cost, at scale: The Digest's Multi-Slide Guide to AltAir. Biofuels

Digest. http://www.biofuelsdigest.com/bdigest/2016/05/19/6 3308/ (2016). Accessed 28 November 2017

54. aireg: INERATEC and Petrixo first new members in 2016. http://www.aireg.de/en/press-releases/416ineratec-and-petrixo-first-new-members-in-2016.html (2016). Accessed 28 November 2017

55. Kotrba R.: Petrixo to build biojet fuel refinery in UAE using UOP technology. Biodiesel Magazine. http://www.biodieselmagazine.com/articles/128947/p etrixo-to-build-biojet-fuel-refinery-in-uae-using-uoptechnology (2014). Accessed 28 November 2017

56. Eni: Green Refinery. https://www.eni.com/en_IT/innovation/technologicalplatforms/green-refinery.page. Accessed 28 November 2017

57. Diamond Green Diesel: https://www.diamondgreendiesel.com/. Accessed 28 November 2017

58. Lane J.: Diamond Green Diesel starts up, largest advanced biofuels facility goes online. Biofuels Digest.

http://www.biofuelsdigest.com/bdigest/2014/05/15/di amond-green-diesel-starts-up-largest-advancedbiofuels-facility-goes-online/ (2014). Accessed 28 November 2017

59. Total: La Mède: Total's first Biorefinery. http://www.total.com/en/energyexpertise/projects/bioenergies/la-mede-total-firstbiorefinery (2017). Accessed 28 November 2017

60. Solazyme: Better Products for People. http://solazymeindustrials.com/solutions/fuel (2014). Accessed 28 November 2017

61. Sustainable Aviation: Sustainable Fuels UK RoadMap. http://www.sustainableaviation.co.uk/wpcontent/uploads/2015/09/SA-SAF-Roadmap-FINAL24-Nov-2.pdf. Accessed 28 November 2017

62. SkyNRG: Sustainable aviation fuel - Technology Section. http://skynrg.com/technology-section/. Accessed 28 November 2017

63. SkyNRG: The Company - About SkyNRG. http://skynrg.com/about-skynrg/. Accessed 28 November 2017

64. Lane J.: Financing aviation biofuels, creatively: The Digest's 2015 8-Slide Guide to SkyNRG and the Fly Green Fund. Biofuels Digest. 
http://www.biofuelsdigest.com/bdigest/2015/11/18/fi nancing-aviation-biofuels-creatively-the-digests2015-8-slide-guide-to-skynrg-and-the-fly-green-fund/ (2015). Accessed 28 November 2017

65. Renewable Energy Group: Biorefineries. http://www.regi.com/aboutreg/locations/biorefineries. Accessed 28 November 2017

66. Amyris: trans-beta-Farnesene. https://farnesene.net. Accessed 28 November 2017

67. Total: Amyris: A cutting-edge biotechnology platform. https://www.total.com/en/energyexpertise/projects/bioenergies/amyris-biotechnologyplatform (2017). Accessed 28 November 2017

68. RÖMPP: Terpene. Georg Thieme, Stuttgart (2009)

69. aireg: Milestone for sustainable aviation: innovative fuel gains approval. http://www.aireg.de/en/pressreleases/333-milestone-for-sustainable-aviation-

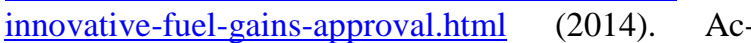
cessed 29 November 2017

70. Bomgardner M.M.: Amyris will sell farnesane plant to DSM. Chemical \& Engineering News 27(47), 11 (2017).

71. DSM: DSM expands strategic alliance with Amyris and acquires Brazilian production facility from Amyris (press release). https://www.dsm.com/corporate/media/informationce nter-news/2017/11/51-17-dsm-expands-strategicalliance-with-amyris-and-acquires-brazilianproduction-facility-from-amyris.html (2017). Accessed 12 December 2017

72. LanzaTech: Innovation - Technical Overview. http://www.lanzatech.com/innovation/technicaloverview/. Accessed 29 November 2017

73. Gevo Inc.: Gevo's alcohol-to-jet fuel meets approved ASTM standard. Biomass Magazine. http://biomassmagazine.com/articles/13078/gevounde fineds-alcohol-to-jet-fuel-meets-approved-astmstandard (2016). Accessed 29 November 2017

74. Gevo: Company Overview - Technology. http://www.gevo.com/about/companyoverview/technology/. Accessed 29 November 2017

75. Gevo: Company Overview - Isobutanol Plant: Luverne,

http://www.gevo.com/about/company-

overview/isobutanol-plant-luverne-minn/. Accessed 29 November 2017

76. Gevo: Company Overview - Biorefinery: Silsbee, Texas. http://www.gevo.com/about/companyoverview/biorefinery-silsbee-texas/. Accessed 29 November 2017

77. Byogy Renewables: Technology. http://www.byogy.com/technology/index.html. Accessed 29 November 2017

78. Swedish BioFuels, Technology. http://www.swedishbiofuels.se/keyproperties. Accessed 29 November 2017

79. ARA: Advanced Biofuels and Renewable Chemicals. https://www.ara.com/capabilities/advanced-biofuels- and-renewable-chemicals. Accessed 29 November 2017

80. Virent: Jet Fuel. http://www.virent.com/products/jetfuel/. Accessed 29 November 2017

81. McCarty D., Doom J.: Kior Inc., Biofuel Company, Files Bankruptcy, Plans Sale. Bloomberg. https://www.bloomberg.com/news/articles/2014-1110/kior-inc-biofuel-company-files-bankruptcy-planssale (2014). Accessed 29 November 2017

82. Licella: Cat-HTR. http://www.licella.com.au/cat-htr/. Accessed 28 November 2017

83. Honeywell UOP: RTPTM Technology for Biomass Conversion. https://www.uop.com/processingsolutions/renewables/technology-for-biomassconversion/. Accessed 28 November 2017

84. Envergent Technologies: RTP'M Technology Converts Low-Value Biomass into a High-Value Liquid Asset-RTP green fuel. https://www.envergenttech.com/technology/. Accessed 28 November 2017

85. Kick T., Kathrotia T, Braun-Unkhoff M., Riedel U.: An experimental and modeling study of laminar flame speeds of alternative aviation fuels. Proc. of ASME Turbo Expo GT2011-45606 (2011)

86. Kick T., Herbst J., Marquetand J., Braun-Unkhoff M., Naumann C., Riedel U.: An experimental and modeling study of burning velocities of possible future synthetic jet fuel. Energy 43(1), 111-123 (2012)

87. Mzé-Ahmed A., Dagaut P., Hadj-Ali K., Dayma G., Kick T., Herbst J., Kathrotia T., Braun-Unkhoff M., Herzler J., Naumann C., Riedel U.: Oxidation of a Coal-to-Liquid Synthetic Jet Fuel: Experimental and Chemical Kinetic Modeling Study. Energ. Fuel 26, 6070-6079 (2012)

88. Dagaut P., Karsenty F., Dayma G., Diévart P., HadjAli K., Mzé-Ahmed A., Braun-Unkhoff M., Herzler J., Kathrotia T., Kick T., Naumann C., Riedel U., Thomas L.: Experimental and detailed kinetic model for the oxidation of a Gas to Liquid (GtL) jet fuel. Comb. Flame 161, 835-847 (2014)

89. Alfa-Bird: Alternative fuels and biofuels for aircraft. EUFP7/2007-2013, grant agreement no 213266. http://www.alfa-bird.eu-vri.eu/. Accessed 28 November 2017

90. Eberius H., Kick, T.: Stabilization of Premixed, Conical Methane Flames at High Pressure. Ber. Bunsen. Phys. Chem. 96(10), 1416-1419 (1992)

91. Braun-Unkhoff M., Kathrotia T., Rauch B., Riedel U.: About the interaction between composition and performance of alternative jet fuels. CEAS Aeronaut. J. 7(1), 83-94 (2016)

92. Joule: Joule completes acquisition of Red Rock Biofuels. Biomass Magazine. http://biomassmagazine.com/articles/12817/joulecompletes-acquisition-of-red-rock-biofuels (2016). Accessed 28 November 2017

93. Lane J.: Heat Death: Joule Unlimited collapses as oil prices flag, time passes, pressure mounts. Biofuels Digest. 
http://www.biofuelsdigest.com/bdigest/2017/07/18/he at-death-joule-unlimited-collapses-as-oil-prices-falltime-passes-pressure-mounts/ (2017). Accessed 29 November 2017

94. Rye L., Blakey S., Wilson C.W.: Sustainability of supply or the planet: a review of potential drop-in alternative aviation fuels. Energ. Environ. Sci. 3, 17-27 (2010)

95. Conconi C.C., Crnkovic P.M.: Thermal behavior of renewable diesel from sugar cane, biodiesel, fossil diesel and their blends. Fuel Process. Technol. 114, 6-11 (2013)

96. Won S.H., Dooley S., Veloo P.S., Wang H., Oehlschlaeger M.A., Dryer F.L., Ju Y.: The combustion properties of 2,6,10-trimethyl dodecane and a chemical functional group analysis. Comb. Flame 161(3), 826-834 (2014)

97. Tekawade A., Oehlschlaeger M.A.: An experimental study of the spray ignition of alkanes. Fuel 185, 381393 (2016)

98. Bloomberg Markets: https://www.bloomberg.com/energy. Accessed 29 November 2017

99. Gevo: Our Markets - Jet Fuel http://www.gevo.com/our-markets/jet-fuel/. Accessed 29 November 2017

100. RÖMPP: Wasserstoff. Georg Thieme, Stuttgart (2004) 